\section{Growth and Flowering Response of Asiatic Hybrid Lilies to Uniconazole}

\author{
Bradford C. Bearce and Suman Singha \\ Division of Plant and Soil Sciences, West Virginia University, \\ Morgantown, WV 26506-6108
}

Additional index words. Lilium lancifolium $\times$ L. $\times$ hollandicum, ancymidol, bulb soak, soil drench

Foliar sprays or soil drench applications of uniconazole control stem elongation of various lilies (Bailey and Miller, 1989a, 1989b). Postplant soil drench applications to Oriental lilies did not provide adequate reduction in stem elongation, and the slow rate of root development may have adversely prolonged uniconazole uptake, thereby reducing inflorescence size (Bailey and Miller, 1989b). Preplant bulb soaks may alleviate the problem of delayed chemical uptake encountered with drench applications and also reduce potential environmental impact due to runoff from drench applications or carry over in the growing medium. The objective of this investigation was to compare the effectiveness of preplant bulb soak and postplant soil drench applications of uniconazole on growth and flowering of Asiatic hybrid lily 'Enchantment' (Lilium lancifolium $\times$ L. $\times$ hollandicum). An additional comparison included a postplant soil drench of ancymidol.

Bulbs of 'Enchantment' lily (16 to $18 \mathrm{~cm}$ in circumference), received from a commercial source on 10 Mar. 1989, were immediately placed in $4.5 \mathrm{C}$ dark storage for 5 weeks. Following storage, 15 bulbs were randomly assigned to each of 11 treatments. For soak applications, bulbs were immersed for $30 \mathrm{~min}$ in 1.5-liter solutions containing 0 to $2 \mathrm{mg}$ uniconazole/liter. Immediately after soaking, bulbs were individually planted in $500-\mathrm{ml}(10 \mathrm{~cm}$ standard $)$ pots in Cornell peatlite mix A and placed in a 29/16C greenhouse. Bulbs for drench applications were similarly planted, and pots were arranged in a randomized complete-block design. Drenches were made when emerging shoots were $2.5 \mathrm{~cm}$ and $100 \mathrm{ml}$ of solution was applied per pot; treatments included uniconazole at 0 to $2 \mathrm{mg} \cdot 1$ iter $^{-1}$ or ancymidol at 2 $\mathrm{mg} \cdot$ liter ${ }^{-1}$.

Day of anthesis was recorded when the first flower of the inflorescence opened. Upon anthesis of the last inflorescence, plant height from soil surface to top of inflorescence and the number of flowers per plant were recorded. Flower width was measured on the largest bloom of each plant. Inflorescence, stem, and bulb dry weights were obtained after drying at 60C. Data were subjected to

Received for publication 17 Oct. 1989. Approved for publication by the Director, West Virginia Agr. and For. Expt. Sta. as Scientific Article no. 2186. We thank Valen USA Corp. for supplying uniconazole. The cost of publishing this paper was defrayed in part by the payment of page charges. Under postal regulations, this paper therefore must be hereby marked advertisement solely to indicate this fact. analysis of variance, single-degree-of-freedom contrasts, and regression analysis.

The preplant bulb soak and the postplant soil drenches of uniconazole reduced plant height (Table 1). The bulb soak was more effective for height control than the soil drench, especially at the lower uniconazole concentrations. Bulb soaks reduced stem dry weight more than the soil applications. Reduction in plant height and stem dry weight by either bulb soaks or soil drenches of uniconazole at $1.0 \mathrm{mg} \cdot$ liter $^{-1}$ were as effective as the ancymidol soil drench at $2.0 \mathrm{mg} \cdot 1$ iter $^{-1}$. At these concentrations, plants were $\approx 30 \mathrm{~cm}$ high, a size aesthetically desirable for the containers.

Flower width (15.1 to $16.0 \mathrm{~cm}$ range) was not influenced by uniconazole applications. Although flower number was not affected by uniconazole concentration, the soil drenches caused a small but significant reduction, compared to the bulb soaks. Soil applications of uniconazole also reduced inflorescence dry weight when compared to the control or the bulb soaks. Soil application of ancymidol or bulb soaks of uniconazole did not influence inflorescence dry weight. This

Table 1. Growth and flowering response of 'Enchantment' lily to concentration and method of application of uniconazole and a drench application of ancymidol.

\begin{tabular}{|c|c|c|c|c|c|}
\hline $\begin{array}{l}\text { Chemical }\left(\mathrm{mg} \cdot \mathrm{liter}^{-1}\right) \\
\text { and application } \\
\text { method }\end{array}$ & $\begin{array}{l}\mathrm{Ht} \\
(\mathrm{cm})\end{array}$ & $\begin{array}{l}\text { Stem } \\
\text { dry wt } \\
\text { (g) }\end{array}$ & $\begin{array}{l}\text { No. } \\
\text { flowers }\end{array}$ & $\begin{array}{l}\text { Inflorescence } \\
\text { dry wt } \\
\text { (g) }\end{array}$ & $\begin{array}{l}\text { Days } \\
\text { to } \\
\text { anthesis }\end{array}$ \\
\hline \multicolumn{6}{|l|}{$\begin{array}{l}\text { Uniconazole preplant } \\
\text { bulb soak }\end{array}$} \\
\hline 0 & 71.1 & 6.0 & 9.1 & 4.4 & 50.6 \\
\hline 0.25 & 43.8 & 4.1 & 9.9 & 5.1 & 52.6 \\
\hline 0.5 & 35.9 & 3.5 & 9.9 & 4.6 & 52.6 \\
\hline 1.0 & 28.3 & 2.8 & 8.9 & 4.4 & 53.0 \\
\hline 2.0 & 26.1 & 2.6 & 9.0 & 4.5 & 53.3 \\
\hline \multicolumn{6}{|l|}{$\begin{array}{l}\text { Uniconazole postplant } \\
\text { soil drench }^{2}\end{array}$} \\
\hline 0 & 69.2 & 6.1 & 9.3 & 4.9 & 49.2 \\
\hline 0.25 & 53.8 & 4.3 & 9.0 & 4.2 & 51.4 \\
\hline 0.5 & 49.6 & 4.1 & 8.6 & 4.1 & 50.1 \\
\hline 1.0 & 30.6 & 3.0 & 8.9 & 4.1 & 52.1 \\
\hline 2.0 & 27.0 & 3.4 & 8.5 & 4.1 & 53.3 \\
\hline \multicolumn{6}{|l|}{$\begin{array}{l}\text { Ancymidol } \\
\text { postplant soil drenchy }\end{array}$} \\
\hline 2.0 & 32.3 & 3.2 & 9.2 & 4.3 & 52.9 \\
\hline Control vs. soak ${ }^{x}$ & $* *$ & $* *$ & NS & NS & ** \\
\hline Control vs. drench ${ }^{\mathbf{x}}$ & ** & ** & NS & $*$ & ** \\
\hline Drench vs. soak & ** & ** & ${ }^{*}$ & * & ** \\
\hline Control vs. ancymidol ${ }^{x}$ & ** & ** & NS & NS & ** \\
\hline \multicolumn{6}{|l|}{ Uniconazole soak } \\
\hline Linear & ** & ** & NS & NS & ** \\
\hline \multicolumn{6}{|l|}{ Uniconazole drench } \\
\hline Linear & ** & ** & NS & NS & ** \\
\hline
\end{tabular}

${ }^{2}$ Corresponding to $0,0.025,0.05,0.1,0.2 \mathrm{mg}$ a.i./pot.

Corresponding to $0.2 \mathrm{mg}$ a.i./pot.

${ }^{\mathrm{x}}$ Control designates $0 \mathrm{mg} \cdot \mathrm{liter}^{-1}$ soak or drench application.

Ns. ${ }^{*} * *$ Contrast or treatment nonsignificant or significant at $\mathrm{P}=0.05$ or 0.01 , respectively. azole provide effective height control of 'En-

Lewis, A.J. and J.S. Lewis. 1981. Improving an- result indicates that the reduction in inflorescence length of Easter and Oriental lilies by soil drenches of uniconazole (Bailey and Miller, 1989) is due to continued uptake following soil treatments.

Variability in response following preplant bulb soaks in growth retardant solutions was noted by Lewis and Lewis (1981). In our study, the variability in plant height in the bulb soak treatments was comparable to or less than that obtained following drench applications of uniconazole. Unlike the 2-sec bulb dips with ancymidol used by Lewis and Lewis (1981), we used a 30-min soak and lower concentrations of uniconazole. This may have enhanced uniformity of uptake of the growth retardant, making it the preferable method of application. Uniconazole and ancymidol applications delayed anthesis. Foliar applications of uniconazole caused similar delays in Easter lily (Bailey and Miller, 1989a) and may be a disadvantage for commercial producers. Bulb dry weight was not influenced by uniconazole applications.

Preplant bulb soak applications of uniconchantment' lily, and unlike soil drench applications, do not undesirably delay uptake of the chemical or adversely affect inflorescence size.

Literature Cited
Bailey, D.A. and W.B. Miller. 1989a. Wholeplant response of Easter lilies to ancymidol and uniconazole. J. Amer. Soc. Hort. Sci. 114:393396.

Bailey, D.A. and W.B. Miller. 1989b. Response of oriental hybrid lilies to ancymidol and uniconazole. HortScience 24:519. cymidol efficiency for height control of Easter lily. HortScience 16:89-90. 